\title{
Gender in the Military: A Phenomenological Study of the Lived Experience of Female Soldiers in the Cameroon Army
}

\author{
Dr. James Kewir, Kiven (Corresponding author) \\ Department of Political Science and Public Administration \\ Faculty of Social and Management Sciences, University of Buea \\ PO Box 63, Buea, Cameroon \\ E-mail: jameskewir@gmail.com \\ Dr. Patience Munge, Sone \\ Department of Law \\ Faculty of Social and Management Sciences, University of Buea \\ PO Box 63, Buea,Cameroon \\ E-mail: pattysonem@gmail.com
}

Received: December 25, 2014 Accepted: February 4, 2015 Published: February 9, 2015

doi:10.5296/ijssr.v3i1.7069

URL: http://dx.doi.org/10.5296/ijssr.v3i1.7069

\begin{abstract}
The number of women engaged in the Cameroonian Army continues to increase over the years, but their involvement is still over-shadowed by that of men. Although the importance of research activities to understand the experiences of women in the military is increasingly accepted, they remain very rare or ignored in Cameroon. This qualitative phenomenological study aimed to reveal and describe the gender experiences of a purposive sample of ten female soldiers in the Cameroonian military. One in-depth interview was conducted with each of the participants. Analysis of the data revealed five themes. The results suggest that the army remains a male dominated environment in which women face unique challenges that can be overcome by adopting coping strategies that depend on one's strength and receiving appropriate support as well as mentorship especially from senior servicewomen.
\end{abstract}


Stereotyping, sexual harassment and underrepresentation in combat arms branches constitute major obstacles to the full integration of female soldiers.

Keywords: Women, Cameroon Army, phenomenology, gender inequality, coping strategies

\section{Introduction}

The number of women serving in the Cameroon military is unprecedented since independence. Compared to men, they are however highly underrepresented. Women are seldom found in combat roles and are poorly represented in leadership positions. In addition to being underrepresented, they face many gender related challenges. Gender refers to the socially determined treatment given to people on the basis of sex or roles that are socially considered appropriate for members of each sex. Gender inequality refers to a situation where there are observable differences in status, influence, and participation between men and women in a given organization or society.

What is known today as the Cameroon Army was created by Ordinance No. 59/57 of 11 November 1959 and placed under the Prime Minister of the then French Cameroons (later East Cameroon). When French Cameroons achieved independence on 1 January 1960, it came under the command of the President. Following the Reunification of English Cameroon (also West Cameroon) with French Cameroon, some 386 soldiers serving in West Cameroon and Nigeria joined their counterparts of the former French Cameroons. Although no law banned the recruitment of women, no women had served in the Army in both territories up to this time. This situation obtained until 1984 when women were recruited into the rank and file of the army for the first time and when the first women were also admitted into the military academy that trains army officers.

From independence to the present, no law has however restricted the recruitment of women or prescribed quotas for recruitment. The law does not also bar women from recruitment into any of the military specialties, including combat. Article 12 of Decree No. 2001/190 of 2001 on the Special Status of Non Commissioned Officers of the Army (Statut Particulier des Personnel Militaires Non Officiers des Forces de Defense) states that "recruitment in the Armed Forces is open to Cameroonians of both sexes ...” Article 2 of Decree No.2001/187 of 2001 Defining the Conditions for the Recruitment and Admission into Military Academies for the Training of Officers also gives equal opportunity for recruitment and admission at all levels of training to Cameroonians of both sexes. As such, there is no explanation for the de facto gender differences in participation observed in the Cameroon Army. In fact, although the number of women serving in the Cameroon military has continued to increase since 1984, they are still largely outnumbered by men. Today, women comprise approximately $10 \%$ of the Cameroon Army and hold less than 2\% of leadership positions. It is only recently; in 2001, that Cameroon had her first female colonel. Since then, seven other women have risen to the rank of colonel. In spite of their low representation, women's roles continue to expand and diversify over time.

Women were integrated into the Rapid Intervention Battalion (known by the French acronym BIR) for the first time in 1997. The last recruitment of women into the BIR took place in 
2000. The BIR is essentially a combat force that was created to serve in high risk operations. Most of the women integrated in to combat jobs, especially the BIR since 1997 have however opted to leave. As such, the BIR in particular is currently an all male force. However, as the case for gender equality gains more ground in Cameroon, and as the number of women in the military and the roles they occupy continue to expand, military women may be increasingly assigned to combat roles. Such development is all the more possible given that 2010 estimates of manpower fit for military service show that women represent $49.3 \%$ (https://www.cia.gov). It is therefore important to understand whether such development will be favorable for women and generally the military.

Gender stereotypes may be associated with the low representation of women but cannot single handedly explain the place of women in the Cameroon Army. While there is growing literature on the experiences of women in the military, it remains limited and largely focused on armies in advanced nations. Also, whereas the integration of women in the military has mostly been treated favorably in the literature, their entry into the military still stands against the traditional belief that women are less efficient combatants. It is, therefore, vital to identify and understand the factors that affect the participation of women in the army and the coping skills they employ.

A study by the Defense Advisory Committee on Women in the Services (OSD DACOWITS, 1951) established by the United States Secretary for Defense in 1951 to make recommendations on ways to increase the number of women on active duty, increase the retention rate of women in the military and maximize the use of their capabilities, showed that mentoring could play an important role in facilitating the integration of women into combat roles. The main challenges identified were: the readiness of men to accept the change, the need for women to work harder to overcome stereotypes, sexual harassment and pregnancy.

In an examination of the factors that may have led to the integration of gender in the US military academies, Irish (2007) observed that there was strong opposition to the integration of women in the Virginia Military Institute (VMI) and West Point in the USA. He found that those who argued against integration believed that the presence of women made the warrior environment in the academy less attractive and that the integration of women into academies whose purpose was to train officers for combat roles was not desirable. The method of training was also considered adversative, involving harsh verbal and physical discipline making it unsuitable for women. Irish's study revealed that while female cadets in West Point faced sexual harassment from male cadets and college staff, this was not a major challenge for those at Norwich and VMI. The reasons advanced for this included the use of differing fitness tests for male and female cadets in West Point whereas female cadets were held to the same standards of tests and efforts made by the administration in VMI and Norwich. He consequently concluded that stereotypes of women constituted the main obstacle to their integration into military academies.

In a study of the role of women in the French Army during wars from the $19^{\text {th }}$ Century onward, Jauneau (2012) also argues that stereotypes of women have historically been the 
main barrier to their integration into the military. Similarly, Smith (2006) found that in Britain, "stereotypical ideals of 'warriors', 'soldiers', the 'military' and assumed traditional male and female gender roles have been used and continue to be used as reasons to prevent women in the military being on equal terms with men as well as prevented women in the military being portrayed and perceived as 'soldiers' as men are". Other studies especially in the USA (Biernatet al., 1998, Boldry et al., 2001; Boyce \& Herds 2003) have supported this view. In spite of the growing interest in this area and the significance of understanding the factors that affect women in the military, an extensive data base search failed to yield any studies that explored the experience of women in the Cameroon Army.

A qualitative study was carried out in Yaoundé and Buea, Cameroon with the aim of understanding the experiences of women in the Cameroon Army. A phenomenological approach was adopted, eliciting a rich verbal description of the lived experience of women in the Cameroon Army from their perspective and analyzing data to create a description of their collective experience. The aim was to provide a deep understanding of how female soldiers experience gender in the Cameroonian military and how this affects their involvement in combat units such as the infantry, armor, special forces, and field artillery positions from a feminist standpoint.

\section{Theoretical Framework and Methodology}

The choice of methodology was informed by the feminist standpoint epistemology. Unlike positivism that asserts the need for objectivity in research, feminist standpoint treats the knower as the source of all knowledge (Harding, 1991).

\subsection{Feminist Sandpoint Epistemology}

Feminist standpoint theory emerged in the 1980s as an attempt to explain the growing successes of feminist research and indict (debunk) masculinist theories of power. Standpoint epistemologists like Hartsock (1983, 1997), Harding (1991, 1993) and Smith (1991) have been influenced considerably by the works of Marx and Lukacs. They have referred to the critique of Western science and rationalism and support for the standpoint of the proletariat by Lukacs and have agreed with Marx's analysis of work and the standpoint of the proletariat. Social life, they argue is structured by hierarchies from which different standpoints emerge. According to Harding (2004), the dominant group in this hierarchy is unlikely to accept oppressive aspects of its own beliefs and practices. Feminist standpoint scholars contend that women gain knowledge from their lived experiences but that these have traditionally been systematically ignored in favour of dominant masculine points of view. Women are therefore in a better position to describe their experiences.

Feminist standpoint has been criticized for essentialising the position of white middle class women and trapping all women into one identity. Critics argue that women are not all the same and may have differing interpretations of marginalization. In spite of such criticism, feminist standpoint scholars like Harding (1991), argued that the oppressed position that women find themselves in, gives them the ability to see things from the perspective of the master and the servant. This unique position of women that Collins (1990) aptly described as 
the concept of outsiders within gives women the capacity to contribute to knowledge in a more superior way than men. This approach is therefore best suited for a study that seeks to unpack the standpoint of women that traditionally have been ignored or misinterpreted by excluding them from research and policy making.

\subsection{Research Design}

A phenomenological design was chosen for this study. According to Wertz (2005), phenomenology is based on the assumption that all human consciousness is practical. Actors act with purpose to implement goals on the basis of their perceptions and receptivity. Phenomenology aims to uncover the structure, essence and meaning of phenomena as they are lived so that veridical interactions with the world can be uncovered (Husserl, 1913). Hence, although everybody's experience is unique, there is an essence or essences, to the shared experience of a phenomenon (Patton, 1990). Phenomenology can therefore not be dismissed as being subjective. Rather, by putting individuals at the centre, it allows for inter-subjective insight into the essence of the phenomena under investigation. Phenomenology is well suited to research on gender in the military as a result of the shared holistic view that 'individuals need to be understood as a whole person within a particular situation, not separated from the environments in which they function'(Kelly, 1996, p. 238).

\subsection{Participants, Sampling and Recruitment}

Informant selection is highly relevant for phenomenological research as people are constantly looked upon for knowledge and information. The focus of this study was limited to service women who were willing to share their personal experiences through narrative interviews as described by Jovchelovitch and Bauer (2000).

A purposive sample of women that are serving or have served in the Cameroon Army from 1984 to present and were at least 25 years of age participated in the study. A sample of 3 to 15 participants is recommended by Creswell (2013) for phenomenological research while Polkinghorne (1983) recommends a sample of 5 to 25 participants. This study recruited ten participants, which is above the minimum numbers recommended above to enable adequate interpretations and analyses. The purposive sampling technique, also called judgement sampling, is the deliberate choice of informants based on qualities they posses (Patton, 1990). Criterion sampling which is a type of purposive sampling was used to select all volunteers who fulfilled the predetermined criteria. Males were excluded from participating in this study. Service women were chosen for this study due to their de facto absence from infantry, armor, artillery or other jobs in combat, as well as the lack of literature on female soldiers lived military experiences in the Cameroon Army. All participants had served in the army for at least five years at the time of interview. These criteria helped ensure that those interviewed had a rich experience as women in the Cameroon military.

Recruitment was done in Yaoundé and Buea. Each participant received a written invitation to participate along with an information sheet and a consent form. All the participants who were contacted volunteered and were selected. In order to protect the privacy and confidentiality of participants the sample will not be described in detail. However, some demographic 
characteristics of the respondents may be revealed. Ethical approval was gained for all aspects of the methodology prior to the commencement of data collection.

\subsection{Data Collection}

All participants were approved by the researchers in person and provided with a consent form. All ten participants waived signature on the consent form but verbally agreed to take part in the study. A single in-depth interview was conducted with each of the ten participants. Interviews of 30-60 minute duration took place at participants' homes or workplaces as they preferred. All interviews were conducted in person in from the $1^{\text {st }}$ August to the $20^{\text {th }}$ September 2014. There is a strong likelihood that data collected via personal interviews will be accurate since the interviewer has the opportunity to correct any misconceptions immediately (Miller \& Salkind, 2002).

Personal interviews can however be considered disadvantageous because of the time involved in the interview. Generally, personal interviews require more time than telephone and internet chat interviews. There is also a possibility that the interviewer can influence the responses of the participant via body language (Miller \& Salkind, 2002).

The interview style was an unstructured, conversational interview, as described by Moyle (2002). This approach was selected to allow participants to explore the topic in-depth while also allowing the interviewer to cover broad topics of interest. The use of unstructured interviews in phenomenological studies, allows the researcher to try to understand the complex behavior of members of the society without imposing a structure that may impede the expansion of the reply (Fontana \& Fey, 2005). This makes it possible for rich and detailed descriptive data to be generated. The focus of the interviews was on the low representation of women in the armed forces and their practical absence from combat roles and ways that their contribution could be maximized.

Interviewees were given a written explanation of the objective of the study and interview before being asked to provide demographic information. After this information was provided, they were then asked the broad opening question: 'have you had any stressful or challenging military service experiences that you perceive may be attributed to your gender?' Participants were also asked to describe the strategies they used to cope with these experiences where applicable. Other open-ended questions assisted participants to exhaust the description of their experience. The interviews were audio taped and transcribed verbatim. A typed transcript was returned to participants so that they had the opportunity to add, delete or correct data.

\subsection{Data Analysis}

Data were analyzed using the procedure described by Colaizzi (1978), to develop an essential structure of the phenomenon under study. The researchers took the following steps:

1) The researchers read the transcription of each participant's interview in order to gain a full description of experience of the phenomenon. 
2) The interview transcripts were re-read and the researcher underlined and extracted significant statements from the transcript that directly pertained to the investigated phenomenon: gender in the Cameroon Army.

3) The researchers formulated and wrote the meanings of each significant statement. A strong attempt was made to ensure that the 'formulated meanings' actually reflected what the participants had meant. For this to be possible there was a constant comparison between the original transcript, the statements and the formulated meanings from all the study participants.

4) The formulated meanings were organized into clusters and themes. To validate clusters or themes, the researcher compared them with the original description of the phenomenon.

5) The results of the data analysis were integrated into an exhaustive description of the phenomenon.

6) Finally, to ensure that the research findings were credible, the descriptive results were again returned to the participants to read and assure that their experience had been accurately represented and that their exigencies with regard to anonymity and confidentiality had been respected.

\subsection{Validity and Reliability}

In phenomenological research, the validity of responses is provided by the experience and perceptions of participants (Guba \& Lincoln, 2005). Validity was achieved by applying three strategies. First, a consistent interview technique, involving open-ended, non-leading questions was used. Second, bracketing was applied to identify personal biases and set them aside so that they do not influence the collection and analysis of data (Groenewald, 2004). Third and last is member checking, a technique that involves asking participants to check that the interpretation and analysis of the data by the researcher reveals an accurate picture of their experience.

Reliability was demonstrated through consistency or dependability (Neuman, 2006). Bailey (2006) considered consistency to be an implication of reliability. Reliability was maintained by audio taping all interviews and reviewing each tape with the completed transcripts to make sure the transcripts were accurate. Diligence in recording and transcribing data ensures that responses provide a reliable picture of the experiences and perceptions of participants (Metler \& Charles, 2008, p. 158). To guarantee consistency, the opinion of participants was sought for the same phenomena.

\section{Results}

The objective of this qualitative phenomenological study was to understand and document the lived experience of women in the Cameroon Army so as to identify gender relevant practices that can improve their wellbeing and boost the performance of the service. Demographic information was collected from the participants to facilitate the understanding and interpretation of their experiences. An overview of participant's demographic information is 
presented in Table 1 below.

Table 1. Description of respondents by selected characteristics

\begin{tabular}{lllllll}
\hline Pseudonym & Age & Rank & Status & \multicolumn{1}{c}{ Education } & Children & Combat Deployment \\
\hline Mankah & 26 & PVT 1CL & Single & First Cycle Secondary & 0 & 0 \\
Eposi & 28 & SERG & Single & First Cycle Secondary & 0 & 0 \\
Beri & 27 & PVT 1CL & Single & First Cycle Secondary & 0 & 0 \\
Fadi & 40 & CWO & Married & First Cycle Secondary & 4 & 0 \\
Lum & 41 & CAPT & Single & University & 3 & 0 \\
Jolie & 45 & CWO & Single & First Cycle Secondary & 0 & 0 \\
Enanga & 29 & CORP & Single & First Cycle Secondary & P & 0 \\
Manga & 38 & $1^{\text {ST }}$ LIEUT & Single & Second Cycle Secondary & 0 & 0 \\
Suh & 47 & CAPT & Married & Second Cycle Secondary & 0 & 0 \\
Ngono & 32 & CORP & Single & Second Cycle Secondary & 3 & 0 \\
\hline
\end{tabular}

The age range of participants was from 26 to 47. Two of the participants were Private First Class (PVT 1CL), two were Corporals (CORP), one was a Sergeant (SERG), two were Chief Warrant Officers (CWO), one was a First Lieutenant( $\left({ }^{\text {ST }}\right.$ LIEUT) and two were Captains (CAPT). Two participants were married (all to active duty service men); eight were single. Three participants had dependent children under the age of 21, one was pregnant and six had no children. No participant had been deployed in combat. The participants worked in different military occupational specialties (MOS) identified in fields such as health, justice, administration, food service and supply. One participant had a University degree, three had completed second cycle secondary and six had first cycle secondary education.

Significant statements and their corresponding formulated meanings were organised into theme clusters in line with the procedure outlined by Colaizzi (1978). The analysis of data revealed five themes that were essential to understanding the experience of being female in the Cameroon Army. The themes identified were based on their prevalence within the transcripts alongside individual accounts that captured a unique or in-depth perspective. These themes were:

- Being a service woman is particularly challenging;

- Stereotyping and harassment decreases one's sense of worth and belonging to the service;

- Combat roles are not good for women;

- Servicewomen adopt different coping strategies in the Cameroon Army;

- Supportive leadership and mentoring, especially from senior service women makes all the difference. 


\subsection{Being a Service Woman Is Particularly Challenging}

All participants believed service women faced some unique challenges that made their experience in the army more difficult. The low representation of women, the need to work harder than men and corporeal awareness, were identified by all interviewees as challenges that are unique to women and that made military service for them a daunting experience.

- The low representation of women in the Army. Lum described her experience as: "being a one eyed person in the country of the blind ... It's a man's world.” To Ngono who had served for some time in the infantry, "there are too few women that their voices cannot be heard. You just have to do as the men say. Combat roles are more challenging ... you just find yourself surrounded by men ... you feel you have to be nice to them else no one will come to your rescue if you are in a bad situation, but you can't be sure what you will do to get along well with them.” Eposi explained that: "Servicemen think we are not fit for most military jobs. They consider being under a woman's command demeaning because it's not common for them to receive orders from a woman.”

- Work harder than men. Jolie explained that as a servicewoman, "you need to prove you can do what the servicemen can do.” Enanga perceived that as a female soldier: "you have to do far more work than the men do. You do what you are assigned to do plus what they think you must do because of your gender. No one will understand why you did not serve tea in the office ... you get no assistance for things like that even when you are with men the same rank as you.” Lum explained how: “you cannot rest because they are all trying to see if you can cope. They all act like you have some catching up to do.”

- Corporeal awareness. Participant remarked being more aware of their bodies since they joined the force. Fadi explained that as a female sodier: "it is difficult to feel comfortable around male soldiers, especially because there are always so many of them. [...] It is a real challenge to do anything with the men because you just know they are more focused on your body than on what you are saying or what you are doing." Beri described her experience in the following words: "It's very challenging to be a female soldier because you need to try hard to be the man you can never be. When you do not hide your body parts, the male soldiers just keep looking ... you cannot cover them enough but you just find yourself trying to hide them.” Mankah felt:"servicemen act like they want us out of the army. [...] It is like you have to be a man to be there ... we are not accepted as women. [...] They just walk into your room without knocking and kind of want to be close to see you urinating. It's just not right. [...] It's hard to try very hard to hide your body all the time.”

\subsection{Stereotyping and Harassment Decreases Ones Sense of Worth and Belonging to the} Service

The ten respondents shared their experiences with negative stereotyping since joining the army and their experiences with gender and sexual harassment. Mankah shared her view of 
negative stereotyping of servicewomen: "when you join, it is to date or to have sex. You're just company or some commander's girlfriend. [...] You are a bitch or a 'poule' (hen).” Eposi described how she experienced and perceived negative stereotyping: "It is just not fair to be treated in a way you do not want just because you are a woman. It was very hard in the beginning because you decide to join the force and you are trained for it but servicemen see and treat you as someone that needs help with everything physical. You are forced to accept and act feeble." Suh described how she was stereotyped when she was given her first command assignment: "they look at you like you are a whore. [...] they will say that you are in that position because you slept with a Commander, Colonel or Generall. They will always identity someone of higher rank you must be sleeping with as the logical explanation for your promotion. [...] It is very painful. Gender cannot explain performance. Many servicewomen would do better than their male counterparts even in combat and leadership roles. Such thinking is not helping matters. We would do a lot better if we are just seen as soldiers that we have chosen to be". Lum explained her view of stereotyping of femalle leadership in the army: “The men just don't accept you. They think you cannot lead them because you are 'inferior'. If they had a way, they would never obey your orders and you just know it.”

Participants identified resistance to authority, gossip, rumors and indirect threats as common forms of gender harassment. Some participants explained they felt unsafe because they had either experienced verbal or physical advance of a sexual nature or have heard about incidents of sexual harassment. Gender harassment is a non-sexual form of discrimination that tends to reinforce traditional gender roles when these are considered to have been violated, or to dismiss women's leadership as illegitimate (Miller, 2000). Fadi described her experience with gender harassment in the following words: "one commander made me feel like I had to compete with the men and because I was not doing the exercises like the men he said 'the army is not for the feeble." As concerns sexually harassment, Ngono explained: "I am sure that servicewomen are sexually harassed but it has not happened to me. I worry a lot because it feels like it could happen to me and I am not sure how to deal with it. There is a lot of rumor about it but I have not seen anyone punished for sexually harassing a servicewoman. This is the reason I am scared.”

\subsection{Combat Roles Are Not Good for Women}

Although some women felt that women could do as well and often performed as well as men in physical fitness tests, all ten women opposed the idea of women serving in combat roles. Manga had this to say: "It is not a good idea to encourage women to integrate combat units but it's not also good to ban them from combat roles. There are women that are physically and mentally qualified to serve in and lead infantry platoons but sure there are not as many as men. I don't think those that can, should be prevented from doing so just because they are women, but it would be a disaster to have women who don't want to be there with the men." Beri feared that: "women would be a distraction and important setback for men who may be divided between protecting them and facing the enemy." Lum said: "our bodies are not adapted to prolonged combat as the men's. There are many roles for women in the army but the infantry is not one of them. Most women cannot handle the challenges of the battlefield. A female prisoner of war is likely to suffer twice as much as a male prisoner. It is not 
uncommon for enemies to use captured female soldiers as sex objects in addition to other forms of torture.”“'Our needs make it expensive for us to serve in the infantry. To be effective, even the best of women will need more than what the men need to go to battle and I don't see how those needs can be met," said Fadi. Ngono considered "pregnancy and inappropriate relationships with men during combat," as setbacks for group cohesion. She also felt that "the stress of the battlefield, complete lack of privacy due to living in very close quarters increases the likelihood of sexual harassment and when it happens, it breaks the morale of even the best female soldier.”

\subsection{Servicewomen Adopt Different Coping Strategies in the Cameroon Army}

All participants described coping strategies they used to face the challenges of being female in the army. The strategies described included being tough, trying to be like the men, being very disciplined, humor, seeking information and help, being helpful and staying away from 'male' jobs.

Lum said: "you have to treat them like they treat you. If you are not tough, the men just keep disrespecting you."Suh shared her belief that: "the only way to avoid being run over by the men is to be tough. [...] It's a man's club so if you don't act like them they will treat you like you don't belong or disrespect you. Those women that are too feminine get laughed at." Ngono told servicemen who harassed her in any way: "the next time you try it I'll blow your balls up." She also said: "the worst thing to do here if to be timid. If you don't face them they just think they will get away with anything." Fadi said choosing the right job was important: "You don't want to be where they think you should not be or where you can't meet-up. Stay where you'd have a few sisters to talk to as well and to stand with you if need be. There are many jobs here that we are good at." Enanga and Jolie described how male soldiers were comfortable with servicewomen they found helpful. Jolie said: "if they know they can count on you for something, it's like you cease to be girl in their eyes.” Beri, Mankah, and Eposi said humor made them forget they were in a male dominated environment. They said that good jokes made most men friendly in a positive way because men like jokes. All the participants believed discipline was very important. Suh said: "indiscipline puts you in an awkward situation. The person that is likely to be in a position to cover your mess in a place like this is a man, and you don't want that to happen, especially repeatedly because they won't cover you for nothing. If they can and do, they feel they have earned the right to treat you like a rag."

Most of the participants said that information from the internet and friends in similar situations, help from God and friends enabled them to cope with the stress of being in a relationship and being a servicewoman. Manga shared how internet searches helped her: "there is a lot about challenges women face in the army on the internet now. Reading about the difficulties of keeping a relationship as a servicewoman makes you feel like you are not alone.” Jolie described avoiding relationships with civilians as a way of escaping stress: "Your man will never trust you if he is a civilian because you get to spend many nights out and they just can't stand it. [...] He would think like your male colleagues that you joined to sleep around with other servicemen and what's worse is that because he can't interact with 
people you work with, you are alone to convince him and it's impossible." Suh said that going to church and praying helped her because "by faith you just know God is with you all the time and will see you through all the troubles." Mankah described sharing with older and senior servicewomen as invaluable. "They have been through what you are going through and have survived it. Knowing how they have done it makes a big difference. [...] What is good is that they understand and most are very happy to listen and support." Beri shared how practicing fitness exercises with other female soldiers that were doing better helped her to improve: "It helps when you are not the only woman in the house. The men just think you can't make it so they don't do push-ups with you like you are soldiers. Learning from a sister that does them well is encouraging and you get to believe you can do it too.”

\subsection{Supportive Leadership and Mentoring, Especially from Senior Service Women Makes All the Difference}

Lum, Fadi, Ngono, and Enanga said women need supportive leaders when they are pregnant and raising young children. Fadi concluded that: "without a supportive leader, the last thing that should happen to a servicewoman is to get pregnant. You are refused permission when you badly need it and they don't tell you what the law says about your situation so you get in trouble." Enanga said "the law in Cameroon is very good as concerns the treatment of pregnant servicewomen but if you are ignorant of it and do not have a supportive leader being pregnant can be a nightmare. Some leaders act like it's a crime to be pregnant.”

Ngono and Lum found advice from senior servicewomen to be very useful. Ngono said: "They told me all I needed to know and helped do everything right. Because I had people that understood what I was going through, I had no problem. I have heard many women complain about not being treated well when they were pregnant but it was when I got pregnant for the first time that I really felt like I belonged to a family. I felt proud to be a soldier because of the huge support I received." Lum similarly said: "my commander was supportive and it helped, but he did not know as much about pregnancy as the senior servicewomen I also received support from when I was pregnant with my first child. They made it really easy for me.”

According to study participants mentorship by senior female soldiers is very useful. Eposi said: "seeing another woman like you that has risen through the ranks is very motivating. [...] You learn better when someone like you shows you how to do it.” Beri described how seeing other senior women do physical exercises she considered too tough made her believe she could do them as well and successfully practiced and performed them. Jolie explained that: “if you don't have a senior sister you can look up to, and who is available it's very hard when you join. [...] I was lucky to have someone I was very comfortable to run to for guidance when I joined but there are not enough women in senior ranks and most young servicewomen don't get to benefit from the wonderful support and inspiration of having one.”

\section{Discussion}

The purpose of this study was to provide a deep understanding of how female soldiers experience gender in the Cameroonian military and how this affects their participation in 
combat arms branches. It was also intended to identify practices that could improve the wellbeing of servicewomen and boost the performance of the army.

The results suggest that for participants, gender is still a problem in the Cameroon army in spite of the increase in the number of women and their participation in more roles. Being a servicewoman involves overcoming unique challenges. To the participants, although the challenges made service life really difficult, they could be overcome by adopting the right strategies and having support from the leadership, especially from senior servicewomen.

The participants in this study described a sense of isolation and stress that came from being in a male dominated environment. The data obtained suggest that stress is a major challenge in the life of military women. Demographic data collected revealed that only three of the participants had children and one other was pregnant. Although the participants did not associate their parental status with military related stress, several studies have demonstrated that exposure to severe stress challenges can affect female reproduction (Judd, 1992; Ferin, 1999; Tilbrook, 2002). Barzilai-Pesach et al. (2006), Begall, Mills and Ganzeboom (2012) and Stocker (2013) have shown that irregular work hours and job stress are associated with lower fertility among women. In addition to dealing with stress, the results also show that servicewomen have to cope with isolation, being in a male dominated environment. The idea that the military is a man's world is supported by the view of Kanter (1993i) that the culture of an organization is determined by the group with the largest representation. The finding that women face more and unique challenges is also substantiated in the literature. Kanter (1993) argues that to survive, the least represented (women) need to form alliances. Kanter found that the dominant group held an image of those least represented, that did not match reality and stereotyped based on this imperfect image. This supports the experience of participants with stereotypes and labeling they considered detached from their reality. As the findings show, female soldiers are for example considered weak by their male counterparts whereas they do not perceive themselves as such.

The problem of harassment experienced by participants has also been confirmed by other studies. Street et al. (2009) for example found that over $50 \%$ of servicewomen have experienced some form of harassment. The participants mentioned the fear of sexual harassment as one of the reasons why women should not be deployed in combat. They explained that the likelihood of sexual harassment was high in combat situations. This conclusion was also reached by Duta et al. (2010) in a research showed that more than half of the sample of deployed servicewomen experienced military sexual harassment.

The demographic data collected shows that none of the women in this study had been deployed in combat. The main reasons advanced by participants for the exclusion of women from combat deployment were that it would affect combat effectiveness and that it increased the likelihood of sexual harassment, the uniqueness of the female body and the special needs of women in combat situations. The participants, however, generally agreed that women should not be banned from combat roles because there are women who can cope with battlefield stress.

In spite of the concerns raised about the participation of women in combat roles, it can be 
gleaned from the findings that, increased representation of women in the military, including combat roles and leadership could reduce the incidence of sexual harassment. A decrease in sexual harassment will also boost the morale of female soldiers which in turn will favour unit bonding. This is supported by the view of Weatherhill et al. (2011) who concluded that, gender egalitarian interactions reduce the risk of sexual harassment and mitigate problems relating to performance, stress and unit cohesion for servicewomen in the US Marines. The special needs addressed by participants may also be met if their experiences are considered. The real obstacle to meeting such needs is the absence of their formal recognition or consideration.

Concerns raised about the body of the woman, which are related to those about physical fitness, are probably the result of cultural belief and not reality. As already mentioned, all participants believed some women could perform as well as men on those tests. The study also reveals that with adapted mentoring, the performance of women on these tests could be enhanced. Similar findings were obtained by Irish (2007), Dunivin (1994), Ward (1993) and Franke 1997. As these writings demonstrate, the problem lies with what men and women have been cultured to accept as proper gender roles and not with the effectiveness of servicewomen.

In spite of the challenges faced, this study has shown that service women adopt several coping strategies and that from the experiences of the respondents, these strategies work. The level of coping can be explained by the predominant use of approach coping strategies which are associated with less depression in both men and women ((Ben-Zur \& Zeidner, 1996; Howerton \& Van Gundy, 2009;Penley et al., 2002). Only one participant favoured the use of avoidance coping that has been associated with high depression rates (Kelly et al., 2008; Mazure \& Maciejewski, 2003). Approach coping includes behaviors that are adopted to reduce stress by addressing the problem directly, while avoidance coping refers to behaviors that mitigate stress by distancing oneself from the problem. A good understanding of coping techniques used by women and their effectiveness can help address the problems that affect their integration in combat roles. Mentoring will likely be more effective if the coping strategies of women in the military are better understood especially as they join more specialties in the service. In addition to the coping strategies adopted by participants, supportive leadership and mentoring were also found to be important factors that improved the wellbeing of servicewomen.

The value of supportive leadership and mentorship experienced by participants in this study has been endorsed by Bell and Reardon (2011). They argued that limited access to support by servicewomen could inhibit help-seeking behaviors if they experience unique stressors or are victimized. Participants found support from leaders and mentors to be very useful, especially when it resulted in leaders sharing their experience or understanding of specific challenges faced by servicewomen. Senior female soldiers were described as being more supportive and better mentors because they had better knowledge of and understood the situation of fellow servicewomen. Preference for mentorship and support by senior servicewomen supports the position of feminist standpoint that women gain knowledge from their lived experiences but that this knowledge has been traditionally ignored and is therefore unlikely to be possessed 
by male soldiers.

In this study, although the exploration of the experience of military women offered a beneficial insight into the experience of gender in the Cameroon Army, it also presents some limitations. Participants were expected to reflect upon their role in the military establishment as a whole. However, without experience with combat deployment, this was difficult. Some of the information obtained about the challenges and coping strategies; was consequently speculative and responses may have been different if they had actually been deployed in combat. Another limitation was that, only one interview could be conducted with each participant. According to Streubert and Carpenter (1995), data collection in phenomenological research has to be continuous until saturation. Saturation is the point at which repetition occurs; that is, no new information is obtained and information previously obtained remains unchanged. While repetition was evident in this study, saturation was not reached.

\section{Conclusion}

This study sought to determine how female soldiers experience gender in the Cameroonian military. The main objectives were to uncover the challenges faced by women, the strategies they use to cope and practices that can help improve the wellbeing of servicewomen and boost the performance of the armed forces including in combat.

Virtually no literature existed about servicewomen in the Cameroon Army that offered a relevant and current account about their military service experiences. The findings revealed that active duty women face enormous challenges and that their underrepresentation and the stereotypes that go with it, serve as a de facto ban on their unrestricted participation in combat units. The participants shared coping strategies they have adopted and that they considered effective in dealing with the stress of service life for women in the Cameroon Army. The results obtained, therefore support the argument of feminist standpoint theorists that the oppressed position that women find themselves in, gives women the ability to see things from the perspective of the master and the servant. The unique challenges faced by military women and their presence in the military, puts them in a better position to provide answers to the difficulties they face and contribute to military policy in ways that will improve on their wellbeing and the performance on the service.

There is a strong need for military leadership to work towards creating an enabling environment that values and maximizes the contribution of female soldiers. As the results show, women can perform as well as men in different Military Occupational Specialties including combat units. Performance in physical fitness tests is not a genuine reason for excluding women from combat roles. Women can and do attain the standard of physical readiness commensurate with the active lifestyle and deployability of the military profession. Claims on the distracting nature of women, the perils of feminine qualities and the inherent manliness of war that dominate the debate on gender in the military in Cameroon do not provide a strong base on which to build policy.

A policy framework that takes gender into account will therefore make the necessary 
practical changes that would increase unit cohesion and performance possible. It would create an environment where gender harassment is treated seriously and where there are increased opportunities for mentorship and support for female soldiers. The projected changes will not only improve the wellbeing of women in the military but also generally the performance of the military service.

It is recommended that further research be conducted to examine the factors that motivate women to join the army and how this impacts on their ability to cope with the challenges of military service for women. Research on the experiences of African military women deployed in combat will also expand the scope of understanding into a further dimension of the actual implications of integrating women in combat roles.

\section{Acknowledgement}

The research is financed by the Faculty of Social and Management Sciences, University of Buea. Thanks to Prof. Martha Tumnde, Dean, Faculty of Social and Management Sciences, University of Buea for her support and Prof. Yenshu Emmanuel Vubu, Department of Sociology, Faculty of Social and Management Sciences, University of Buea for his advice and encouragement.

\section{References}

Barzilai-Pesach, V., Sheiner, E., Sheiner, G. P., \& Shoham-Vardi, I. (2006). The Effects of Women's Occupational Psychologic Stress on Outcome of Fertility Treatments. Journal of Occupational and Environmental Medicine, 48, 56-62. http://dx.doi.org/10.1097/01.jom.0000183099.47127.e9

Begall, K., Mills, M., \& Ganzeboom, H. (2012). Non-standard Work Schedules and Childbearing in the Netherlands: A Mixed-method Couple Analysis. Paper presented at the annual meeting of the Population Association of America, San Francisco.

Bell, M. E., \& Reardon, A. (2011). Experiences of sexual harassment and sexual assault in the military among OEF/OIF veterans: Implications for health care providers. Social Work in Health Care, 50(1), 34-50.http://dx.doi.org/10.1080/00981389.2010.513917

Ben-Zur, H., \& Zeidner, M. (1996). Gender differences in coping reactions under community crisis and daily routine conditions. Personality and Individual Differences, 20, 331-340. http://dx.doi.org/10.1016/0191-8869(95)00173-5

Biernat, M., Crandall, C. S., Young, L. V., Kobrynowicz, D., \& Halpin, S. M. (1998). All that you can be: Stereotyping of self and others in a military context. Journal of Personality and Social Psychology, 75(2), 301-317. http://dx.doi.org/10.1037/0022-3514.75.2.301

Boldry, J., Wood, W., \& Kashy, D. A. (2001). Bias in the Evaluation of Women Leaders: Gender Stereotypes and the Evaluation of Men and Women in Military Training. Journal of Social Issues, 57(4), 689-705. http://dx.doi.org/10.1111/0022-4537.00236

Boyce, L. A., \& Herd, A. M. (2003). The relationship between gender role stereotypes and requisite military leadership characteristics. Sex Roles: A Journal of Research, 49(7-8), 
365-378. http://dx.doi.org/10.1023/A:1025164221364

Colaizzi, P. F. (1978). Psychological Research as the Phenomenologist Views it. In R. S. Valle' \& M. King (Eds.), Existential-phenomenological alternatives for psychology. New York: Oxford University Press

Collins, P. H. (1990). Black feminist thought: Knowledge, consciousness, and the politics of empowerment. Boston, MA: Unwin Hyman.

Creswell, J. W. (2013). Qualitative inquiry and research design: Choosing among five approaches (3rd ed.). Thousand Oaks, CA: Sage Publications.

Decree No. 2001/187 of 25. (July 2001). Article 2, Defining the Conditions for the Recruitment and Admission into Military Academies for the Training of Officers

Decree No. 2001/190 of 25. (July 2001). Article 12, Special Status of Non Officer Military Personnel of the Armed Forces (StatutParticulier des Personnel Militaires Non Officiers des Forces de Defense)

Dunivin, K. O. (1994). Military culture: Change and continuity. Armed Forces \& Society, 20, 531-547. http://dx.doi.org/10.1177/0095327X9402000403

Dutra, L., Grubbs, K., Greene, C., Trego, L. L., McCartin, T. L., Kloezeman, K., \& Morland, L. (2010).Women at war: Implications for mental health. Journal of Trauma \& Dissociation, 12, 25-37. http://dx.doi.org/10.1080/15299732.2010.496141

Ferin, M. (1999). Stress and the reproductive cycle. J ClinEndocrMetab., 84, 1768-1774. http://dx.doi.org/10.1210/jcem.84.6.5367

Fiala, I. J. (2008). Unsung Heroes: Women's Contributions in the Military and why their Song goes Unsung. In H. Carreiras \& G. Kümmel (Eds.), Women in the Military and in Armed Conflict. Nertherlands: VS Verlag, Fur Sozialwissenschaften.

Fontana, A., \& Frey, J. H. (2005). The interview: From neutral stance to political involvement. In N. K. Denzin \& Y. S. Lincoln (Eds.), The Sage handbook of qualitative research (3rd ed., pp. 695-727). Thousand Oaks, CA: Sage Publications

Francke, L. (1997). Ground zero: The gender wars in the military. New York: Simon \& Schuster.

Groenewald, T. (2004). A phenomenological research design illustrated. International Journal of Qualitative Methods. Retrieved from http://www.ualberta.ca/ iiqm/backissues/3_1/pdf/groenewald.pdf

Harding, S. (1987). Feminism and methodology: Social science issues. Indianapolis, IN: Open University Press.

Harding, S. (2004). Identifying standpoints. In S. Harding (ed.), The feminist standpointtheory reader (p. 23). New York: Routledge.

Hartsock, N. C. M. (1983). Money, Sex, and Power: Toward a Feminist Historical 
Materialism. New York: Longman.

Hartsock, N. C. M. (1997). Standpoint Theories for Next Century. In S. J. Kenney \& H. Kinsella (Eds.), Politics and Feminist Standpoint Theories. New York: Haworth Press.

Howerton, A., \& Van Gundy, K. (2009). Sex differences in coping styles and implications for depressed mood. International Journal of Stress Management, 16, 333-350. http://dx.doi.org/10.1037/a0016843

Central Intelligence Agency (CIA). (n.d.). The World Fact Book, Retrieved from https://www.cia.gov/library/publications/the-world-factbook/geos/cm.html

Husserl, E. (1913). Ideas: General Introduction to Pure Phenomenology. Routledge (2012).

Irish, K. (2007). What's this about a few good men? Gender integration in the U.S. military academies. Minerva Journal of Women and War, 1(1), 19-44. http://dx.doi.org/10.3172/MIN.1.1.19

Jauneau, E. (2012) «Les femmes dans l'armée française pendant les guerres (XIXe-XXe siècles): histoire, historiographie et problématique de genre» Encyclo. Revue de l'ecoledoctorale ED. 382, 57-71

Jovchelovitch, S., \& Bauer, M. W. (2000). Narrative interviewing. In M. W. Bauer \& G. Gaskell (Eds.), Qualitative researching with text, image and sound (pp. 57-74). London: Sage.

Judd S. J. (1992). Pathophysiological mechanisms of stressinduced chronic anovulation. In K. E. Sheppard, J. H. Boublik \& J. W. Funder (Eds.), Stress and reproduction (pp. 253-265). New York: Raven Press.

Kanter, R. M. (1993). Men and Women of the Corporation (2nd ed.). New York: Harper Collins.

Kelly, G. (1996). Understanding Occupational Therapy: A hermeneutic approach. British Journal of Occupational Therapy, 59, 237-242.

Kelly, M. M., Tyrka, A. R., Price, L. H., \& Carpenter, L. L. (2008). Sex differences in the use of coping strategies: Predictors of anxiety and depressive symptoms. Depression and Anxiety, 25,839-846.http://dx.doi.org/10.1002/da.20341

Lammey, M. (n.d.). A Defense of Epistemological Standpoint Theory. Miami Dade College, Hialeah, Retrieved from https:/www.mdc.edu/hialeah/Polygon2013/docs2013/A\%20Defense\% 20of\%20Epistemological

Lukacs, G. (1971). History and Class Consciousness: Studies in Marxist Dialectics. Trans Rodney Livingstone. Cambridge: the MIT Press.

Marx, K. (1976). Capital: A Critique of Political Economy. Volume 1. Trans. Ben Fowkes. England: Penguin Books.

Mazure, C. M., \& Maciejewski, P. K. (2003). The interplay of stress, gender and cognitive 
style in depressive onset. Archive of Women's Mental Health, 6, 5-8. http://dx.doi.org/10.1007/s00737-002-0161-3

Miller, D. C., \& Salkind, N. J. (2002). Handbook of Research Design and Social Measurement (6th ed.). Thousand Oaks, CA: SAGE Publications

Miller, D. C., \& Salkind, N. J. (2002). Handbook of research design \& social measurement (6th ed.). Thousand Oaks: Sage Publications.

Miller, L. L. (2000). Not just weapons of the weak: Gender harassment as a form of protest for Army men. In M. Baca Zin, P. Hondagneu-Sotelo \& M. A. Messner (Eds.), Gender through the prism of difference (pp. 409-428). Boston, MA: Allyn and Bacon.

Ministry of Defence. (2002).Women in the Armed Forces. Retrieved August 3, 2014, fromwww.mod.org

Moustakas, C. E. (1994). Phenomenological research methods. Thousand Oaks, CA: Sage Publications.

Moyle, W. (2002). Unstructured interviews: challenges when participants have a major depressive illness. Journal of Advanced Nursing, 39(3), 266-273. http://dx.doi.org/10.1046/j.1365-2648.2002.02273.x

Office of the Secretary of Defense (OSD) Defense Advisory Committee on Women in the Service (DACOWITS). (1951). Retrieved from http://dacowits.defense.gov/

Ordonnance N 59/57 du 11 Novembre 1959 portant Organisation Générale de la Défense.

Patton, M. Q. (1990). Qualitative Evaluation and Research Methods (2nd ed.). Thousand Oaks: Sage Publications

Penley, J. A., Tomaka, J., \& Wiebe, J. S. (2002). The association of coping to physical and psychological health outcomes: A meta-analytic review. Journal of Behavioral Medicine, 25, 551-603. http://dx.doi.org/10.1023/A:1020641400589

Polkinghorne, D. (1983). Methodology for the human sciences: Systems of inquiry. Albany, NY: State University of New York Press

Smith, A. C. (2006). Women in the British Military: A History of Women's Entry into the Official British Military Forces and an Analysis of Ideologies and Their Effects on Women's Acceptance within Today's British Military. Centre for Interdisciplinary Gender Studies, University of Leeds.

Smith, D. E. (1987). The Everyday World as Problematic: A Feminist Sociology. Boston: Northeastern University Press.

Smith, D. E. (1990). The Conceptual Practices of Power. Grand Rapids, Michigan: Northeastern University Press.

Stocker, L. (2013). Women Working Shifts are at Greater Risk of Miscarriage, Menstrual Disruption, and Subfertility. Paper presented at the annual meeting of European Society of 
Human Reproduction and Embryology, London.

Street, A. E., Vogt, D., \& Dutra, L. (2009). A new generation of women veterans: Stressors faced by women deployed to Iraq and Afghanistan. Clinical Psychology Review, 29, 685-694. http://dx.doi.org/10.1016/j.cpr.2009.08.007

Struebert, H. J. \& Carpenter, D. R. (199). Qualitative research in nursing advancing the humanistic imperative. Philadelphia: J. B. Lippincott.

Struebert, H. J., \& Carpenter, D. R. (1995). Qualitative research in nursing advancing the humanistic imperative. Philadelphia: J. B. Lippincott

Tilbrook A. J., Turner A. I., \& Clarke, I. J. (2002). Stress and reproduction: central mechanisms and sex differences in non-rodent species. Stress, 5, 83-100. http://dx.doi.org/10.1080/10253890290027912

Ward, D. (1993). Women not welcome-yet. Navy Times, January 4, 30.

Wertz, F. J. (2005). Phenomenological research methods for counseling psychology. Journal of Counseling Psychology, 52, 167-177. http://dx.doi.org/10.1037/0022-0167.52.2.167

Wood, J. T. (2009). Feminist Standpoint Theory. Encyclopedia of Communication Theory. Thousand Oaks, CA: SAGE, 2009. 397-99. Retrieved from http://www.sagepub.com/edwards/study/materials/reference/77593_2.2ref.pdf

\section{Copyright Disclaimer}

Copyright for this article is retained by the author(s), with first publication rights granted to the journal.

This is an open-access article distributed under the terms and conditions of the Creative Commons Attribution license (http://creativecommons.org/licenses/by/3.0/). 